Does “Good Cospa” Encourage Consumer Reviews and Purchases? Effects of Price Image as a Retailer on Word-of-Mouth and Buying Behavior

\title{
“コスパの良い”は消費者のロコミと 購買を促すのか?
}

\section{一 小売店舗の価格イメージがロコミ行動と購買行動に与える影響 —1)}

\author{
Takashi Teramoto*1, Shoji Misaka ${ }^{* 2}$ \\ 横浜国立大学大学院 国際社会科学研究院 \\ 寺本 高 \\ 流通経済研究所 \\ 三坂 昇司

\footnotetext{
${ }^{* 1}$ Faculty of International Social Sciences, Yokohama National University, Japan, teramoto-takashi-yg@ynu.ac.jp

*2 The Distribution Economics Institute of Japan, Japan, shoji_misaka@dei.or.jp
}

\begin{abstract}
The authors clarify the effect of the price image that retailers refer to as "good cospa" (cospa is the abbreviation of "cost performance" which means "value for money") on consumer reviews and purchases. Through empirical analysis, consumer-generated content is created experimentally to capture the difference in Word-of-Mouth (WOM) behavior under different expressions regarding price images as retailers. In addition, they also capture the differences in the buying behavior at the target stores before and after the WOM behavior. As a result, participants who contact post information related to "good cospa" are more likely to: (1) respond more frequently than post information related to "cheap," (2) have more contact with the topic of "price" through "quality," (3) have more contact with the topic of "fun" through "quality," and (4) the purchase amount and unit purchase price at the target stores increased. The results show the effectiveness of the keyword "good cospa" in stimulating WOM and purchasing related to retail stores.
\end{abstract}

Keyword : Value for money, Price image, Word-of-Mouth, Buying behavior, User generated content

要約 : 本稿では,「コスパの良い」という小売店舗の価格イメージ情報が消費者の口コミや購買に与える影響について明らかに した。実証分析では，消費者生成型コンテンツを実験的に作成し，小売店舗の価格イメージ情報に関する異なる刺激提示の状況 下での口コミ行動の差異を捉えるのに加え，ロコミ行動前後の被験者の購買行動の差異についても捉えた。その結果，「コスパ の良い」に関する投稿情報に接触した消費者は,「安い」に関する投稿情報に接触した消費者に比べて〕返信回数が多い, (2)「品 質」を通じての「価格」という話題に多く接触している, (3)「品質」を通じての「楽しい」という話題に多く接触している, (4) 対象店舗での購買量や購買商品単価が増加した，の4 点が明らかになった。本稿の成果は, 小売店舗に関するロコミや購買を喚 起するうえで,「コスパの良い」というキーワードの有効性を示している。

キーワード : コスパ，価格イメージ，ロコミ，購買行動，消費者生成型コンテンツ

Information : Received 11 May 2020; Accepted 25 May 2020

\section{I.はじめに}

近年,「コスパ」という言葉が多用されている。「コス パ」は, かつては車, 電化製品といった買回品やホテル, 旅行ツアーといったサービス財を対象に多用される言葉
であった。しかし近年では,「やっぱ, コスパ!」という キャッチコピーのテレビコマーシャルを展開する大手スー パーマーケットが現れたり（Sendenkaigi, 2017），スー パーマーケットが展開するプライベートブランドの競争 軸のひとつとして「コスパ」という表現が用いられる （Nikkei, 2013）など, 加工食品や日用雑貨品のような最 
寄品とそれを扱う業態もこの言葉を用いられる対象に なっている。よって，従来は「安い」というものが，消 費者がスーパーマーケットに対して抱く評価の観点で あったが，いまでは「コスパの良い」というのも評価の 観点になっているのではなからうか。

店舗に対する「安い」，つまり価格を軸にした小売イ メージに関する研究は多岐にわたって行われている (Hamilton \& Chernev, 2013)。しかしこの「安い」という イメージとニュアンスの異なる「コスパの良い」という 小売店舗の価格イメージが消費者の行動にもたらす影響 については十分に議論されていない。先述のように,「コ スパの良い」が消費者における評価の観点になってきて いる可能性を踏まえると,「コスパの良い」という小売店 舗の価格イメージが消費者の口コミや購買行動に与える 影響を議論することは意義があろう。

そこで本稿では,「コスパの良い」という小売店舗の価 格イメージに関する情報が消費者の口コミや購買にどの ように影響を与えるのかを明らかにする。具体的には， 小売店舗の価格イメージ情報に関する異なる刺激提示を 設定した消費者生成型コンテンツを実験的に作成し，異 なる刺激提示の状況下での口コミ行動の差異を捉えるの に加え, ロコミ行動前後の被験者の購買行動の差異につ いても捉える。

\section{II. 先行研究}

先行研究のレビューでは, 小売店舗の価格イメージの 1つである「コスパの良い」の捉え方を踏まえたうえで， 小売店舗の価格イメージに関する諸研究について扱う。

\section{1.「コスパの良い」の捉え方}

「コスパ」とは，コストパフォーマンスの略であり，あ る製品やサービスの費用（コスト）と，それがもたらす 効果・性能（パフォーマンス）とを対比させたものであ る。ここでいうパフォーマンスとは，製品を製造，販売 する供給者側の視点による表現であり，消費者などの需 要者側の視点による表現としては便益（ベネフィット） が用いられる。
Ueda（2004）は，コストとベネフィットを分離させて 対比する考え方の草分けは価值工学にあることを指摘し ているが，この価値工学の考え方を基に，需要側である 消費者の知覚概念を取り入れたのが Monroe（1990）で ある。Monroe（1990）は，消費者が製品に対して知覚す る獲得価值について, 知覚獲得価値＝知覚ベネフィット ／知覚犠牲，という式を示している。Ueda（2004）はこ の Monroe（1990）の考え方を修正し, 製品の知覚価值 =知覚ベネフィット／知覚ライフサイクルコストという 式を提案している。つまり, 消費者が抱く製品の知覚価 值は, 知覚ベネフィットと知覚コストのトレードオフに よって成り立っているのである。

「安い」と「コスパの良い」という言葉は, 共に消費者 の店舗に対する知覚価值を意味した言葉になるが，それ では, これらの知覚価值は知覚ベネフィットと知覚コス トの関係がどのような状態になることを指すのであろう か。Ono（2014）は，顧客が知覚する品質レベルの高低 と顧客が負担するコストの高低によるサービスに対する 知覚価値の類型化を示している。その中で品質レベルが 高く, コストが低いサービスをコストパフォーマンスの 高い「スマート・エクセレンス」なサービスであると指 摘している。この点を踏まえると,「安い」は, 知覚べネ フィットの高低を問わず，とにかく知覚コストが低い製 品・サービスを提供する店舗に対する知覚価值を指して おり，「コスパの良い」は知覚ベネフィットが高く，から 知覚コストが低い製品・サービスを提供する店舗に対す る知覚価值を指していると捉えることができる。

\section{2. 小売店舗の価格イメージ}

知覚コストが伴った知覚価值の捉え方として，製品・ サービスに対する価格イメージがある。価格イメージに 関する研究は多岐にわたるが，中でも「小売店舗イメー ジとしての価格イメージ」という捉え方に焦点を当て, 小売店舗の価格イメージの形成要因，小売店舗の価格イ メージが消費者行動にもたらす影響について見てみる。

まず, 小売店舗の価格イメージの形成要因については, 小売店舗が持つそれ以外の属性との関係を示した研究と 消費者特性との関倸を示した研究がある。前者では, 店 舖の物理的特性として, 内装 (Baker, Parasuraman, Grewal, 
\& Voss, 2002）などが，店舗の品揃えとして，品揃え商品 の価格帯の違い (Hamilton \& Chernev, 2010), 商品カテ ゴリー特性（Lourenço, Gijsbrechts, \& Paap, 2015）が, サービス品質として，提供サービスの水準（Brown, 1969）, 従業員の雲囲気（Baker et al., 2002）がある。後 者では，消費者が持つ価格感度の違い（Kaul \& Wittink, 1995），価格知識の違い（Mägi \& Julander, 2005)，市場の 達人（マーケット・メイブン）度の違い（Feick \& Price, 1987）がある。

次に，小売店舗の価格イメージが消費者行動に与える 影響として，参照価格の形成（Mazumdar, Raj, \& Sinha, 2005), 店舗選択 (Grewal \& Marmorstein, 1994), 購買量 (Van Heerde, Gijsbrechts, \& Pauwels, 2008) などが明らか にされている。

\section{3. 先行研究の課題}

以上，小売店舗の価格イメージの 1 つである「コスパ の良い」の捉え方を踏まえたうえで，小売店舗の価格イ メージに関する諸研究について見た。その結果，(1)「安 い」と「コスパの良い」という小売店舖の価格イメージ は, 消費者の知覚価值を構成する知覚ベネフィットと知 覚コストのポジションが異なると考えられ得ること，(2) 小売店舗の価格イメージは，価格自体への評価だけでな く，店舗の品揃えや内装，サービス水準，消費者の特性 によって形成されること, (3)小売店舗の価格イメージは, 店舗選択と購買量の促進につながること, の 3 点がわ かった。しかし, これらの先行研究の課題として 2 点挙 げられる。

1つめは，高価格イメージないしは低価格イメージの 店舗というように，小売の価格イメージが高低の 1 つの 軸のみによる議論に留まっている。先述の知覚価值を構 成する知覚ベネフィットと知覚コストの 2 つの軸による 関係を踏まえると，知覚ベネフィットと知覚コストが共 に高い状態または共に低い状態のイメージについての把 握に留まっており,「コスパの良い」のように, 知覚ベネ フィットは高いが知覚コストは低いという状態を踏まえ た小売の価格イメージに関する議論がなされていないこ とである。

2 つめは, 小売店舗の価格イメージの把握では, 把握
対象となる消費者の個々人の評価や行動経験を捉えるこ とに留まっており，ある消費者による評価や行動経験に 関する情報が流れて，その流れた情報に他の消費者が接 触するという消費者間の情報共有行動，いわゆるロコミ への影響については捉えられていないことである。消費 者の来店行動や店舗内行動におけるモバイルを通じた情 報接触の重要性が増している（Shankar, Inman, Mantrala, Kelley, \& Rizley, 2011）ことや，消費者間でのロコミの重 要性が企業のマーケティング活動以上に増している （Lamberton \& Stephen, 2016）という指摘を踏まえると, 小売店舗の価格イメージに関するロコミの影響を捉える ことには大きな意義があろう。

以上 2 点の課題を踏まえ, 本稿では,「コスパの良い」 という小売店舗の価格イメージ（以下，“コスパ”）に関 する情報が, 従来議論されている「安い」という小売店 舗の価格イメージ（以下，“安い”）に関する情報に比べ て, 消費者の口コミや購買にどのように影響を与えるの かを明らかにすることを目指す。そのうえで，具体的な 研究課題として，(1) “コスパ”に関する消費者の投稿情 報に対して，他の消費者はどのように反応するのか，(2) “コスパ”に関する投稿情報に反応した他の消費者は, 具 体的にどのような投稿内容に接触しているのか，(3) “コ スパ”に関する投稿情報に接触した消費者は, 投稿対象 となった店舗での購買行動が変わるのか, の 3 点につい て明らかにしていく。

\section{III. 仮説}

先述の 3 点の研究課題に関する具体的な仮説を設定 する。

\section{1.「“コスパ”に関する投稿情報への反応」の仮説}

先述の小売店舗の価格イメージに関する先行研究の中 でも, 低価格のイメージは消費者の店舗選択の促進 (Grewal \& Marmorstein, 1994）や購買量の増加（Van Heerde et al., 2008）につながるといった購買行動面での ポジティブな側面がある一方, みすぼらしく, 粗雑な店 舖のイメージ（Baker et al., 2002）や品切れの多い店舖の 
イメージ (Anderson, Fitzsimons, \& Simester, 2006) のよ うに，認知・態度面でのネガティブな側面もある。逆に 高価格のイメージは, 高水準のサービスを提供するイメー ジ（Brown, 1969）や楽しそうで熟練の雾囲気を持つ従業 員がいるイメージ（Baker et al., 2002）のように，認知・ 態度面でのポジティブな側面がある。

“コスパ”は，先述のように，知覚ベネフィットが高 く，かつ知覚コストが低い製品・サービスを提供する店 舗に対する知覚価值を指していると捉えることができる が，このうち知覚ベネフィットが高いという側面に焦点 を当てると，“コスパ”は，高価格イメージと同様の知覚 ベネフィットを得ることができ，それによって高価格イ メージと同様のポジティブな認知や態度形成がなされる ものと捉えられる。また，このポジティブな認知や態 度の状態を準拠集団による価值表出的影響（Park＆ Lessig, 1977）になぞらえると，“コスパ”の店舗を利用 することは，ポジティブな自己表現につながり，他者か らほめられたいという期待にもつながると捉えられる。

これらの点を踏まえると，“コスパ”に関する投稿情報 に返信することは，“安い”に関する投稿情報に返信する ことに比べ，よりポジティブな自己表現につながり，他 者からほめられたいという期待にもつながるため, より 積極的に返信することが考えられる。以上より，仮説 1-1 を設定する。

仮説 1-1：“コスパ”に関する投稿情報に接触した消費者 は，“安い”に関する投稿情報に比べて返信回 数が多い

また，投稿情報の有用性という点では，品質に関する言 葉が多い投稿情報（Siering, Muntermann, \& Rajagopalan, 2018）は有用性に関する反応が強いという指摘もある。 このことから, 知覚ベネフィットが高く, かつ知覚コス トが低い状態を指す“コスパ”に関する投稿情報は，知 覚コストが低い状態のみを指す“安い”に関する投稿情 報に比べて，品質をはじめとした功利的な情報が充実し ており，それに対して“いいね”をプッシュするといっ た有用性に関するポジティブな反応が積極的になされる ことが考えられる。以上より，仮説 1-2 を設定する。
仮説 1-2：“コスパ”に関する投稿情報に接触した消費者 は，“安い”に関する投稿情報に比べて“いい ね”プッシュ回数が多い

\section{2.「“コスパ”に関する投稿内容項目への接触」の仮説}

先述の仮説 1-2 の導出に際し, 知覚ベネフィットが高 く，かつ知覚コストが低い状態を指す“コスパ”に関す る投稿情報は, 知覚コストが低い状態のみを指す“安い” に関する投稿情報に比べて, 品質をはじめとした功利的 な情報が充実していることが考えられると指摘している。 一方，知覚コストが低い状態のみを指す“安い”に関す る投稿情報には，価格に関する情報が多く含まれている ことが考えられる。このことから，“コスパ”に関する投 稿情報に反応した消費者は, “安い”に関する投稿情報に 反応した消費者に比べて, 価格に関する投稿情報に少な く，品質に関する投稿情報に多く接触することが考えら れる。以上より，仮説 2-1 および 2-2 を設定する。

仮説 2-1 : “コスパ”に関する投稿情報に反応した消費者 は，“安い”に比べて「価格」の内容項目の接 触回数が少ない

仮説 2-2：“コスパ”に関する投稿情報に反応した消費者 は, “安い”に比べて「品質」の内容項目の接 触回数が多い

また, 先述の仮説 1-1の導出に際し, “コスパ”は, 高 水準のサービスを提供するイメージ（Brown, 1969）や楽 しそうで熟練の䨌囲気を持つ従業員がいるイメージ (Baker et al., 2002）のように，ポジティブな認知や態度 形成がなされるものと捉えられると指摘している。この ことから, “コスパ”に関する投稿情報に反応した消費者 は, “安い”に関する投稿情報に反応した消費者比べて, 楽しい状況に関する投稿情報に多く接触することが考え られる。以上より，仮説 2-3 を設定する。

仮説 2-3：“コスパ”に関する投稿情報に反応した消費者 は, “安い”に比べて「楽しい」の内容項目の 接触回数が多い 


\section{3.「“コスパ”に関する投稿情報への接触と購買行動」} の仮説

先述の仮説 1-1 の導出に際し, 低価格のイメージは消 費者の店舗選択の促進（Grewal \& Marmorstein, 1994）や 購買量の増加（Van Heerde et al., 2008）につながるといっ た購買行動面でのポジティブな側面があることを指摘し たが, 知覚コストが低い状態に加え, 知覚ベネフィット が高い状態を指す “コスパ”に関する投稿情報は，知覚 コストが低い状態のみを指す “安い”に関する投稿情報 よりも，購買量の増大を促すことが考えられる。このこ とから，“コスパ”に関する投稿情報に接触した消費者 は，“安い”に関する投稿情報に反応した消費者比べて， 投稿情報の対象となった店舗での購買単価, 購買点数が 増加することが考えられる。以上より，仮説 3-1 と 3-2 を設定する。

仮説 3-1：“コスパ”に関する投稿情報に接触した消費者 は, “安い”に比べて UGC 交流後の来店当た り購買単価が高くなる

仮説 3-2：“コスパ”に関する投稿情報に接触した消費者 は，“安い”に比べて UGC 交流後の来店当た り購買点数が増える

また、“コスパ”に関する投稿情報に接触した消費者 は，知覚コストの低さと知覚ベネフィットの高さのバラ ンスで知覚価值を捉えることが考えられる。一方，“安 い”に関する投稿情報に接触した消費者は，知覚コスト の低さのみで知覚価値を捉えることが考えられる。これ らの点を踏まえると, “コスパ”に関する投稿情報に接触 した消費者は，“安い”に関する投稿情報に反応した消費 者に比べて，購買商品の単価が高くなることが考えられ る。以上より，仮説 3-3 を設定する。

仮説 3-3：“コスパ”に関する投稿情報に接触した消費者 は，“安い”に比べて UGC 交流後の購買商品 単価が高くなる

\section{IV. データ}

先述の仮説を検証すべく，消費者間の口コミの媒体と なる消費者生成型コンテンツを試験的に作成し（以下， $\mathrm{UGC}$ ), 消費者パネル (以下, 参加者 ${ }^{2)}$ ) を募ってその UGC に参加し，参加者間で投稿・反応の交流をしても らった。その交流を通じて, 参加者の (1)UGC 交流履歴, (2)UGC で交流する前（交流前）と交流した後（交流後） の質問票回答, (3)UGC 交流前後の購買履歴, の 3 点のシ ングルソースデータを構築した 3 )。各データの特徴につ いて以下説明する。

\section{UGC 交流履歴}

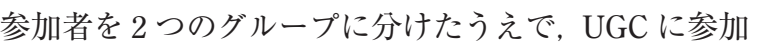
してもらい，その交流の結果となる投稿・反応履歴を収 集した。その際，2つの UGC グループ間の交流を分断 し，それぞれの UGC グループ内のみで交流してもらっ た。2つのUGCグループには, 価格イメージに関する異 なる表現のお題を交流開始時に投げかけている。具体的 には，一方のグループには「コスパの良いスーパーにつ いて語ろう」(以下 “コスパ”）という书題を最初に提示 し，もう一方のグループには「安いスーパーについて語 ろう」(以下，“安い”）というお題を提示した。そのうえ で，両グループの参加者に対し，「少なくとも 1 回は自 分から投稿する」ことを教示した。参加者には，これら のお題を起点にして関連した話題を投稿してもらい，そ れらの投稿に対するリアクションとして，返信をしたり， 「いいね」を押したりする形で交流をしてもらった。これ らの㧍題について UGC で交流した期間は 3 日間である。 参加者は, “コスパ”と“安い”のそれぞれで 189 名, 182 名, 計 371 名である。

“コスパ”と“安い”の各参加者による交流の結果, “コ スパ”と“安い”の延べ投稿数 4 ) はそれぞれ 204 件と 219 件の合計 423 件であった。このうち, 投稿件数上位 3 社 に関する投稿数の分布について, “コスパ”（N=189）

“安い” $(\mathrm{N}=182) \times$ 投稿数（0 件， 1 件， 2 件）の度 数の $\chi^{2}$ 検定を企業別に行ったところ，第 1 位企業と第 2 位企業では“コスパ”と“安い”の間で投稿数の差がな 
いが，第 3 位企業ではその差があることがわかった 5)。 この傾向は，第 1 位企業と第 2 位企業では，参加者が接 触する投稿情報量は“コスパ”と“安い”の間で偏りが ないものの，第 3 位企業では偏りがあることを示してい る。よって第 3 位企業の投稿情報を除外し, 最終的に上 位 2 社の投稿情報を用いることとする。

この上位 2 社に関する投稿情報を用いて，参加者 371 名 $\times$ 対象企業 2 社による延べ参加者 742 件の投稿情報へ の接触指標と反応指標のデータセットを作成した。投稿 情報はテキストを中心とした質的データのため，それを 量的デー夕に変換するためのコーデイングを行った。投 稿情報の内容に関するコーディング項目は，対象企業に 関するサービス (価格, 品質), 印象（楽しい）の 2 区 分 3 項目を扱った。これらの項目に該当する投稿内容に ついて，ポジティブな内容には 1 点，ネガティブには-1 点のスコアを付与する形でコーディングを行った。

このコーディングされた項目を用い，延べ参加者の投 稿情報への接触指標を作成した。ここでの接触指標には， 延べ参加者が対象企業に関する投稿に対して初回に反応 （返信または“いいね”プッシュ）するまでに接触した投 稿情報の累積回数を用いた。過去の研究においても，広 告接触の累積効果 (Berman, 2018) や UCG 上に展開され る多数の支持情報を知覚する（Berger, 2014）という事象 があるように，返信，または“いいね”プッシュという ような UGC 上での反応表示をする際には，その前に投 稿された類似情報にも累積的に接触していると捉えるの が適切である。よってここでは，初回に反応するまでに， 今までに投稿された類似情報に一通り接触していると捉 え，初回に反応するまでに投稿された項目スコアの合計 值である「各項目への累積接触回数」を接触指標とした。 また，反応指標については，先述のように，返信または “いいね”プッシュがUGC 上での反応表示となることか ら,「返信回数」と「“いいね”プッシュ回数」を用いる。

\section{UGC 交流前後の質問票回答}

参加者には, UGC での交流開始前と交流終了後の 2 回 にわたり，質問票調查を行った。交流開始前の調查では， 参加者を“コスパ”と“安い”の 2 つのグループに割り 付けるうえで，デモグラフィックとサイコグラフィック
の観点からグループ間の均質性を確保するための情報取 得を目的とした。前者に関しては，居住地域と世帯のラ イフステージの均質性を確保することに主眼を置き, 居 住地 (都県), 年代, 未既婚, 子供の有無, 世帯年収の 5 項目を聴取した。後者に関しては, 通常の UGC での交 流活動や購買行動の均質性を確保することに主眼を置き, ソーシャルネットワーキングサービス（以下 SNS）の利 用頻度 (Twitter, Facebook, Instagram) と各 SNS の関与状 況（投稿する, リアクションする，閲覧する），業態別の 買物頻度（総合スーパー，食品スーパー，コンビニエン スストア，ドラッグストア，インターネット販売）の計 17 項目について聴取した。

交流終了後の調查では，参加者を“コスパ”と“安い” の 2 つのグループに分け，それぞれ異なる表現のお題を 提示したことへの認識度合いを確認する（操作チェック） ための情報取得を目的とした。具体的には，“コスパ” と“安い”の 2 つのグループに対して，それぞれが提示 された打題の表現について, 共通の 2 項目「商品の品質 が良いスーパーについての表現だと思う」「全体的に価格 が安いスーパーについての表現だと思う」を 7 点尺度で 聴取した。“コスパ”と“安い”の有効サンプル数は, UGC 参加者数と同様に，それぞれ 189 名と 182 名である。

\section{UGC 交流前後の購買履歴}

さらに参加者の UGC 交流前後, 計 30 日間の購買履歴 も収集した。具体的な収集方法として，参加者には交流 開始前の 9 日間，交流中の 3 日間，交流終了後の 18 日 間の計 30 日間の食品購入に関わる全てのレシートを提 出してもらい, それらを基に, 各参加者の購入店舗, 購 入日時, 購入商品, 購入金額, 購入点数についてデー夕 化を行った 6)。

このデータのうち, UGC 交流開始前の 9 日間を「UGC 開始前」, 交流終了後の 18 日間を「UGC 終了後」に区分 し, UGC 開始前と UGC 終了後の両期間において対象企 業での購買履歴を持つ参加者（購買履歴保有者）を抽出 した。UGC 参加者のうち，購買履歷保有者数は “コス パ”と“安い”のそれぞれで 39 名, 37 名, 計 76 名である。

この購買履歴から, 検証に用いる購買指標として, 購 買量の観点から「来店当たり購買単価」(金額基準) と 
「来店当たり購買点数」(数量基準) を, 購買価格の観点 から「購買商品単価」をそれぞれ作成した7)。

\section{V. 分析結果}

先述の指標を用いて仮説検証を行っていく。

\section{1. 均質性チェックと操作チェック}

“コスパ”（N=189）と“安い”（N=182）の 2 つのグ ループに分割したことに対する，参加者の割付のグルー プ間の均質性チェックと, 各グループに対して表現の異 なる小売イメージ情報の刺激提示（操作）に対する，各 グループの操作性チェックを行う。

まず，グループ間の均質性チェックについては, IV. 2.において示した“コスパ”と“安い”の間で参加者 のデモグラフィック 5 項目とサイコグラフィック 17 項 目の合計 22 項目が均等に割り付けられていることを確 認する。“コスパ”／“安い” ×各項目の $\chi^{2}$ 検定をそれ ぞれ行った結果, 22 項目すべての項目において $10 \%$ 水 準（両側検定）でも有意とならなかった。この結果より， “コスパ”と“安い”の間で参加者の割付に差がなく, 均 質的であることが示された。

次に，各グループの操作チェックについては, “コス パ”と“安い”の 2 つのグループの参加者がそれぞれ表 現の異なる小売イメージ情報の刺激を提示されたことに 対する認識の差異の度合いを確認する。ここでは, “コス パ”(“安い”) のグループに対して提示された「コスパの 良い（安い）スーパー」は, 「商品の品質が良いスー パー」および「全体的に価格の安いスーパー」の 2 つの 項目をどのくらい表現しているかについて 7 点尺度で聴 取した回答スコアを用い, 一元配置分散分析を行った。 その結果,「商品の品質が良いスーパー」については, “コ スパ”（ $\mathrm{M}=5.26, \mathrm{SE}=.09 ）$ の方が“安い”（ $\mathrm{M}=2.69$, $\mathrm{SE}=.09)$ よりも高く $\left(F(1,369)=442.8, p<.0001, \eta^{2}=.55\right)$, 「全体的に価格の安いスーパー」については, “コスパ” $(\mathrm{M}=4.72, \mathrm{SE}=.09)$ の方が “安い”（ $\mathrm{M}=6.21, \mathrm{SE}=.09)$ よりも低い $\left(F(1,369)=148.7, p<.0001, \eta^{2}=.29\right)$ ことが示 された。また，これら 2 つの項目の相関分析を“コス
パ”と“安い”のグループ別に行った結果, “コスパ” $(r=$ $-.05, p=.51)$ は有意な相関がなく, “安い” $(r=-.38, p<$. 0001）は負の有意な相関があることが示された。これら の結果は,「商品の品質が良いスーパー」と「全体的に価 格の安いスーパー」の 2 つの項目に対する参加者の認識 が，“コスパ”では排反関係にあり，“安い”では比例の 関係にあることを示している。つまり, “コスパ”では品 質の良さに対して必ずしも安さを期待している訳ではな く, “安い”では「安かろう, 悪かろう」という認識があ ることが言える。以上の結果より，“コスパ”と“安い” の 2 つのグループの参加者間では, 品質と価格の関係に 対する認識の差を識別できていることが示された。

\section{2. “コスパ”に関する投稿情報への反応}

まず，UGC 交流履歴を用い, “コスパ”と“安い”と いう，表現の異なる小売イメージ情報の刺激提示を踏ま えて展開された投稿情報に対し，参加者の反応が異なる のかについて明らかにする。

まず，投稿情報に対する反応の指標として，返信回数 と“いいね”プッシュ回数を用い, これらの行動回数が “コスパ”（N=378）と“安い”（ $\mathrm{N}=364 ）$ のグループ間 で差異があるかについて一元配置分散分析を行った。 その結果, 返信回数については, “コスパ” $(\mathrm{M}=.13$, $\mathrm{SE}=.02 ）$ の方が“安い”（ $\mathrm{M}=.07, \mathrm{SE}=.02 ）$ よりも多い ことが示された $\left(F(1,740)=4.0, p=.04, \eta^{2}=.01\right)$ 。しかし, “いいね”プッシュ回数については, “コスパ”（M=.40, $\mathrm{SE}=.08 ）$ と“安い”（ $\mathrm{M}=.43, \mathrm{SE}=.08 ）$ の間では有意な 差がないことが示された $\left(F(1,740)=.1, p=.82, \eta^{2}=.00\right)$ 。 よって，仮説 1-1 は支持，仮説 1-2 は不支持となった。

この結果をまとめると, “コスパ”に関する投稿情報に 接触した消費者は, “安い”に関する投稿情報に接触した 消費者に比べ,「返信」という労力のかかる反応をより積 極的にすることが明らかになった。しかし，返信に比べ て労力のかからない“いいね”をプッシュする行動につ いては積極性に違いがないことが明らかになった。

\section{3. “コスパ”に関する投稿内容項目への接触}

次に, 対象企業に関する投稿情報の内容項目への接触 状況が異なるのかについても明らかにする。先述の分析 
の対象となった“コスパ”と“安い”のそれぞれの参加 者のうち，投稿情報に対して返信または“いいね”プッ シュしたことのある，いわゆる反応経験者を対象に, “コ スパ”（N=81）と“安い” $(\mathrm{N}=73)$ のグループ間で投稿 情報の内容項目への接触回数に差異があるかについて一 元配置分散分析を行った。

その結果, サービスのうち,「価格」については, “コ スパ”（ $\mathrm{M}=3.58, \mathrm{SE}=.62)$ の方が“安い”（ $\mathrm{M}=6.60$, $\mathrm{SE}=.66)$ よりも少ない $\left(F(1,152)=11.1, p=.001, \eta^{2}=.07\right)$ が,「品質」では，“コスパ”（M=.93, $\mathrm{SE}=.13 ）$ の方が

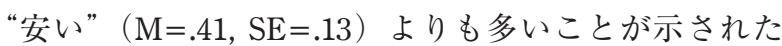
$\left(F(1,152)=8.0, p=.01, \eta^{2}=.05\right)$ 。よって, 仮説 $2-1$ と仮説 $2-2$ は共に支持となった。

印象の「楽しい」については, “コスパ”（ $\mathrm{M}=.37$, $\mathrm{SE}=.06)$ の方が“安い”（ $\mathrm{M}=.20, \mathrm{SE}=.05 ）$ よりも多い ことが示された $\left(F(1,152)=4.8, p=.03, \eta^{2}=.03\right)$ よって, 仮説 2-3 は支持となった。

これらの結果をまとめると，サービスの「価格」につ いては, “コスパ”よりも“安い”の参加者の接触回数が 多く，逆に「品質」については，“コスパ”の方が“安 い”よりも参加者の接触回数が多いことがわかった。そ こで「品質」が “コスパ”と「価格」の媒介関係にある のかについて，媒介分析（Zhao, Lynch, \& Chen, 2010）を 用いて明らかにする。媒介分析には Preacher and Hayes （2004）によるSPSS マクロを適用し，ブートストラップ 法を用いた。その結果,「品質」の媒介を通じた小売イ メージ情報（“コスパ”＝1 vs. “安い”＝0）が「価格」 に与える間接効果は正に有意となった（b=2.09, $\mathrm{SE}=.78$; $95 \% \mathrm{CI}=[.61,3.65]) 。 こ の$ 媒介分析の結果も踏まえると， “安い”の参加者は「価格」の話題ばかりに多く接触して いる一方，“コスパ”の参加者は「品質」があってこその 「価格」という話題に多く接触していることが言える。

さらに, ここで挙げた「品質」だけでなく, 印象の「楽 しい」についても, “コスパ”の方が“安い”ょりも参加 者の接触回数が多いことがわかった。そこで，「品質」 が“コスパ”と「楽しい」の媒介関係にあるのかについ て，先述と同様に媒介分析を行った。その結果，「品質」 の媒介を通じた小売イメージ情報 (“コスパ”＝1 vs. “安 い”＝0）が「楽しい」に与える間接効果は正に有意と なった（b=.10, $\mathrm{SE}=.05 ; 95 \% \mathrm{CI}=[.02, .22] ） 。 こ の$ 媒介分 析の結果も踏まえると, “コスパ”の参加者は「品質」が あってこその「楽しい」という話題に多く接触している ことが言える。

\section{4. “コスパ”に関する投稿情報への接触と購買行動}

そして, UGC 交流前後の購買履歴を用い, 参加者の購 買行動に影響があったのかについても明らかにする。こ こでは，対象企業での購買履歴保有者を対象に，“コス パ”（ $\mathrm{N}=39 ）$ と“安い”（ $\mathrm{N}=37 ）$ の各グループにおい て, UGC 開始前と UGC 終了後の間で購買指標に差異が あるかについて，対応のある $t$ 検定を行った。

その結果，来店当たり購買単価については，“コスパ” は UGC 開始前（M=1,642.43, $\mathrm{SE}=380.51 ）$ と UGC 終了 後（M=2,684.78, $\mathrm{SE}=516.42 ）$ では有意な差があるが $(t(38)=-2.1, p=.04, r=.11)$, “安い” は UGC 開始前 $(\mathrm{M}=1,763.06, \mathrm{SE}=389.89)$ と $\mathrm{UGC}$ 終了後（M=2,526.63, $\mathrm{SE}=394.35)$ では有意な差がなかった $(t(38)=-1.7, p=.10$, $r=.07) 。 こ の$ 結果は, “コスパ”は UGC 交流後に来店当 たり購買単価が高くなっているが, “安い”のそれは変化 がないことを示している。よって，仮説 3-1 は支持と なった。

来店当たり購買点数については, “コスパ”は UGC 開始前 $(\mathrm{M}=9.59, \mathrm{SE}=2.01)$ と $\mathrm{UGC}$ 終了後 $(\mathrm{M}=14.14$, $\mathrm{SE}=2.19 ）$ では有意な差があり（ $t(38)=-2.0, p=.05$, $r=.10)$, 同じく“安い”も UGC 開始前 $(\mathrm{M}=8.57$, $\mathrm{SE}=1.68 ）$ と $\mathrm{UGC}$ 終了後（M=13.54, $\mathrm{SE}=1.96 ）$ では有 意な差があった（ $t(38)=-2.4, p=.02, r=.14)$ 。この結果 は, “コスパ”と“安い”は共に UGC 交流前後の当たり 購買点数が増えていることを示している。よって, 仮説 3-2 は不支持となった。

購買商品単価については, “コスパ”は UGC 開始前 （M=160.69, $\mathrm{SE}=6.96 ）$ と $\mathrm{UGC}$ 終了後（ $\mathrm{M}=216.38$, $\mathrm{SE}=23.04 ）$ では有意な差があるが $(t(38)=-2.3, p=.03$, $r=.12)$ ，“安い”は UGC 開始前 $(\mathrm{M}=187.17, \mathrm{SE}=14.24)$ と UGC 終了後 $(\mathrm{M}=205.15, \mathrm{SE}=8.99)$ では有意な差がな かった（ $t(38)=-1.2, p=.23, r=.04)$ 。この結果は, “コス パ”は UGC 交流後に購買商品単価が高くなっているが, “安い”のそれは変化がないことを示している。よって, 
仮説 3-3 は支持となった。

これらの結果をまとめると, “コスパ”に関する投稿情 報に接触することによって, 参加者の来店当たり購買単 価, 来店当たり購買点数, 購買商品単価が増加すること が明らかになった。つまりUGCでの交流を経て，より 高額の商品を, より多くの点数分買うようになり, その 結果, 1 回の買物時における購買単価が増加しているこ とが言える。“コスパ”という表現は, 来店した時の購買 内容に変化を促す刺激であることを示していると言え よう。

\section{VI. まとめ}

本稿では,「コスパの良い」という小売店舗の価格イ メージに関する情報が消費者の口コミや購買にどのよう に影響を与えるのかを明らかにした。そこから得られた 知見について, 学術的貢献, 実務的示唆の点から述べ, 本稿の限界と今後の課題についても触れたい。

\section{1. 学術的貢献}

本稿の学術的貢献として, 2 点挙げられる。

まず，「コスパの良い」という，知覚ベネフィットは高 くかつ知覚コストは低いという状態を踏まえた小売の価 格イメージが消費者の消費者の行動に与える影響を明ら かにしたことである。具体的な知見として，(1) “コスパ” に関する投稿情報に接触した消費者は, “安い”に関する 投稿情報に比べて返信回数が多いこと，(2)“安い”に関 する投稿情報に反応した消費者は,「価格」の話題ばかり に多く接触している一方，“コスパ”に関する投稿情報に 反応した消費者は「品質」があってこその「価格」とい う話題に多く接触していること，(3) “コスパ”に関する 投稿情報に反応した消費者は，「品質」があってこその 「楽しい」という話題に多く接触していること, (4)“コス パ”に関する投稿情報に接触することによって, 参加者 の来店当たり購買単価, 来店当たり購買点数, 購買商品 単価が増加する，の 4 点を示した。

次に，小売店舗の価格イメージが消費者間の口コミに もたらす影響を明らかにしたことである。具体的な知見
は先述の(1)と(2)に重複するが, 従来の小売店舗の価格イ メージの把握では, 把握対象となる消費者の個々人の評 価や行動経験を捉えることに留まっており，ある消費者 による評価や行動経験に関する情報が流れて，その流れ た情報に他の消費者が接触するという消費者間の情報共 有行動への影響については捉えられていなかった。この 点を明らかにできたことは意義ある成果であると言え よう。

\section{2. 実務的示唆}

本稿の知見は， 2 点の実務的示唆も含んでいる。

まず，「コスパの良い」という表現は「安い」という表 現に比べて, 小売店舗に関する口コミ行動を促し，また 対象店舗での購買促進にもつながることである。“安い” という表現は従来から頻繁に使われているが, 先行研究 で指摘されてきているように, 認知・態度面でのネガティ ブな側面もある。それに対し，ポジティブな自己表現に つながり，他者からほめられたいという期待にもつなが り得る“コスパの良い”という表現は，消費者による口 コミや購買を喚起するうえで, 今後の小売店舗における 有力なコミュニケーションのキーワードとして検討して いくべきであろう。

次に，実証分析で扱った調査用 UGC の仕組みが，今 後の小売企業によるデジタル・コミュニケーションの方 法に活用でき得ることである。具体的には，小売企業の 各社はモバイルアプリの開発とサービス提供に躍起に なっているが, 顧客への一方的な情報提供の色彩が強く, 小売業と顧客間の双方向のコミュニケーションという段 階には程遠いというのが現状であろう。そのような中で, 本稿で扱った内容は, 今後, 小売アプリのコンテンツの 一つとしてユーザーレビュー機能を搭載し，顧客に対し てそのレビュー機能への投稿の喚起次第によっては, 顧 客間での交流が盛り上がり, 来店促進や買上促進に活用 していけると言えよう。

\section{3. 限界と今後の課題}

本稿の限界と今後の課題についても 4 点触れておき たい。

まず，本稿で扱った購買行動では，対象店舗の購買経 
験者を対象にしたリピートに関する行動に限定されてお り，購買未経験者によるトライアルに関する行動を考慮 できていないことである。今後は,「コスパの良い」とい うロコミがトライアルの来店行動につながるのかについ て明らかにすることが必要である。

次に，本稿で扱った分析対象の小売企業は，UGC 内で の投稿数が多い企業に限定していることである。投稿数 が多いということは，元来，話題性の高い小売企業であ ることを意味する。今後は，話題性の必ずしも高くない 小売企業を対象に，話題性を高めるための知見づくりが 必要である。

そして，本稿では，「コスパの良い」というイメージが もたらす影響の把握に留まっていることである。今後は, どうやれば「コスパの良い」と思ってもらえるのか，と いうように，「コスパの良い」という小売イメージ形成の 規定要因を明らかにすることが必要である。

最後に，他のプロモーションとの比較をできていない ことである。「コスパの良い」という小売イメージの口コ ミが購買行動にポジティブに影響することが示されたが, これらの影響が既存の小売プロモーションに比べて影響 力が強いのかそうでないのかについても，費用対効果の 点も含めて明らかにする必要がある。

\section{注}

1）本稿は, 科学研究費助成事業（課題番号 $18 \mathrm{H} 00882$ 及び 18K01873）による研究成果の一部である。また，本稿の執 筆・精査に当たり, 斉藤嘉一先生 (明治学院大学), 清水聰 先生（慶應義塾大学）, 星野崇宏先生 (慶應義塾大学), 特 集号担当編集委員の石淵順也先生（関西学院大学）より貴 重なコメントを頂戴した。ここに記して感謝の意を申し上 げたい。

2）参加者は女性に限定した。女性に限定した理由は, スーパー マーケットは女性が主力の客層であることと，男女混合の 構成によって UGCでの交流が滞る懸念を回避するためで ある。

3） シングルソースデータは流通経済研究所主催の WADAI プ ロジェクトにおいて収集したものを用いている。プロジェ クト参加企業各位に対し，ここに記して感謝の意を申し上 げたい。

4）延べ投稿数とは，投稿数 $\times$ 投稿対象小売業数を示す。

5）“コスパ” “ “安い”別の投稿数度数分布（人数）は, 投稿 数 0 件, 1 件, 2 件の順に, 第 1 位企業では, “コスパ” (147, $40,2)$ “安い” $(145,36,1), \chi^{2}(2,371)=.43, p=.81$ 第 2 位企業 では, “コスパ” $(153,35,1)$ “安い” $(151,30,1)$, $\chi^{2}(2,371)=$ $27, p=.88$ 第 3 位企業では, “コスパ” $(177,12,0)$ “安い”
$(158,22,2), \chi^{2}(2,371)=5.89, p=.05$ となる。この結果から, 第 1 位と第 2 位企業は“コスパ”と“安い”の分布に扔い て有意な差がないが，第 3 位企業は $5 \%$ 水準で有意な差が あることが言える。

6）参加者の購入レシートのデータ化に際し, 横浜国立大学寺 本ゼミ伊藤玉緒, 大石智広, 笠倉結理, 金島夏菜子, 芝山 協介, 馬場棨南, 松岡紀歩, 吉原千尋（2019 年 3 月所属当 時；五十音順）の諸君より作業協力をいただいた。ここに 記して感謝の意を申し上げたい。

7）来店当たり購買単価・購買点数, 購買商品単価の算出方法 については, Teramoto（2011）を参照のこと。

\section{References}

Anderson, E. T., Fitzsimons, G. J., \& Simester, D. (2006). Measuring and mitigating the costs of stockouts. Management Science, 52(11), 1751-1764. doi: 10.1287/mnsc.1060.0577

Baker, J., Parasuraman, A., Grewal, D., \& Voss, G. B. (2002). The influence of multiple store environment cues on perceived merchandise value and patronage intentions. Journal of Marketing, 66 (April), $120-141$. doi: 10.1509/jmkg. 66.2.120.18470

Berger, J. (2014). Word of mouth and interpersonal communication: A review and directions for future research. Journal of Consumer Psychology, 24(4), 586-607. doi: 10.1016/j.jcps. 2014.05.002

Berman, R. (2018). Beyond the last touch: Attribution in online advertising. Marketing Science, 37(5), 771-792. doi: 10.1287/ mksc.2018.1104

Brown, F. E. (1969). Price image versus price reality. Journal of Marketing Research, 6 (May), 185-191. doi: 10.1177/ 002224376900600207

Feick, L. F., \& Price, L. L. (1987). The market maven: A diffuser of marketplace information. Journal of Marketing, 51 (January), 83-97. doi: 10.1177/002224298705100107

Grewal, D., \& Marmorstein, H. (1994). Market price variation, perceived price variation, and consumers' price search decisions for durable goods. Journal of Consumer Research, 21(3), 453-460. doi: 10.1086/209410

Hamilton, R., \& Chernev, A. (2010). The impact of product line extensions and consumer goals on the formation of price image. Journal of Marketing Research, 47 (February), 51-62. doi: 10.1509/jmkr.47.1.51

Hamilton, R., \& Chernev, A. (2013). Low prices are just the beginning: Price image in retail management. Journal of Marketing, 77 (November), 1-20. doi: 10.1509/jm.08.0204

Kaul, A., \& Wittink, D. R. (1995). Empirical generalizations about the impact of advertising on price sensitivity and price. Marketing Science, 14(3, Supplement), G151-160. doi: 10.1287/mksc. 14.3.G151

Lamberton, C., \& Stephen, A. T. (2016). A thematic exploration of digital, social media, and mobile marketing: Research evolution from 2000 to 2015 and an agenda for future inquiry. Journal of Marketing, 80 (November), $146-172$. doi: 10.1509/jm.15.0415 
Lourenço, C. J. S., Gijsbrechts, E., \& Paap, R. (2015). The impact of category prices on store price image formation: An empirical analysis. Journal of Marketing Research, 52 (April), 200-216. doi: 10.1509/jmr.11.0536

Mägi, A., \& Julander, C. R. (2005). Consumers' store-level price knowledge: Why are some consumers more knowledgeable than others? Journal of Retailing, 81(4), 319-329. doi: 10.1016/ j.jretai.2005.02.001

Mazumdar, T., Raj, S. P., \& Sinha, I. (2005). Reference price research: Review and propositions. Journal of Marketing, 69 (October), 84-102. doi: 10.1509/jmkg.2005.69.4.84

Monroe, K. B. (1990). Pricing: Marketing profittable decisions, 2nd ed. McGraw-Hill Series in Marketing. New York: McGrawHill.

Nikkei. (2013). PB vs NB “Cospa” de tsukaiwake hinshitsu ya kakaku, hinmokugotono syouhisyahyouka wo tetteihikaku. Nikkei Consumer Insights, June, 14-19.（日経産業地域研究所 (2013).「PB vs NB，「コスパ」で使い分け品質や価格，品 目ごとの消費者評価を徹底比較」『日経消費インサイト』 6 月号, 14-19) (In Japanese)

Ono, J. (2014). Smart excellence: Customer management through focalization and value co-creation with customer. Hitotsubash $i$ Business Review, 61(4), 56-75.（小野譲司（2014）。「スマー ト・エクセレンス 焦点化と共創を通した顧客戦略」『一橋 ビジネスレビュー』61(4), 56-75) (In Japanese)

Park, C. W., \& Lessig, V. P. (1977). Students and housewives: Differences in susceptibility to reference group influence. Journal of Consumer Research, 4(2), 102-110. doi: 10.1086/ 208685

Preacher, K. J., \& Hayes, A. F. (2004). SPSS and SAS procedures for estimating indirect effects in simple mediation models. Behavior Research Methods, Instruments, \& Computers, 36, 717-731. doi: 10.3758/BF03206553

Sendenkaigi. (2017). Stripe, Seiyu, Nisshin hoka hansoku keyperson 26 no tyakuganten (3). Hansokukaigi, May. Retrieved from https://mag.sendenkaigi.com/hansoku/ 201705/key-persons-view/010483.php (April 10, 2020)（宣伝 会議（2017）。「ストライプ, 西友, 日清ほか販促キーパー ソン 26 の着眼点（3）」『販促会議』5 月号）(In Japanese)

Shankar, V., Inman, J. J., Mantrala, M., Kelley, E., \& Rizley, R. (2011). Innovations in shopper marketing: Current insights and future research issues. Journal of Retailing, 87(S1), s29s42. doi: 10.1016/j.jretai.2011.04.007

Siering, M., Muntermann, J., \& Rajagopalan, B. (2018). Explaining and predicting online review helpfulness: The role of content and reviewer-related signals. Decision Support Systems, 108, 1-12. doi: 10.1016/j.dss.2018.01.004

Teramoto, T. (2011). Usage for FSP data. In Distribution Economics Institute of Japan (Eds.). Shopper marketing (pp. 201-227). Tokyo: Nikkei Publishing. (寺本高 (2011). 「FSP データの活用法」流通経済研究所 (編)『ショッパー・ マーケティング』pp. 201-227, 日本経済新聞出版社) (In Japanese)

Teramoto, T. (2019). Branding for grocers. Tokyo: Chikura
Publishing. (寺本高（2019）.『スーパーマーケットのブラ ンド論』千倉書房) (In Japanese)

Ueda, T. (2004). Shohisya niokeru kachi to kakaku. The Journal of the Department of Economics of Gakushuin University, 41(2), 75-88.（上田隆穂（2004）。「消費者における価值と価格」 『学習院大学経済論集』41(2),75-88) (In Japanese)

Van Heerde, H. J., Gijsbrechts, E., \& Pauwels, K. (2008). Winners and losers in a major price war. Journal of Marketing Research, 45 (October), 499-518. doi: 10.1509/jmkr.45.5.499

Zhao, X., Lynch Jr., J. G., \& Chen, Q. (2010). Reconsidering Baron and Kenny: Myths and truths about mediation analysis. Journal of Consumer Research, 37(2), 197-206. doi: 10.1086/ 651257

\section{寺本 高（てらもとたかし）}

横浜国立大学 大学院国際社会科学研究院 教授 1998 年慶応義塾大学商学部卒業, 2011 年筑波大学大学院ビ ジネス科学研究科博士後期課程修了, 博士 (経営学)。流通 経済研究所主任研究員, 明星大学准教授, 横浜国立大学准 教授を経て，2020 年より現職。

\section{三坂 昇司（みさか しょうじ）}

流通経済研究所 主任研究員

2005 年中央大学商学部卒業, 2010 年中央大学大学院戦略経 営研究科 (中央大学ビジネススクール) 修了。千葉大学大 学院融合理工学府博士後期課程在籍。IT 関連企業を経て, 2010 年流通経済研究所入所。 